\title{
The IncI Plasmids R144, R64 and Collb Belong to One Exclusion Group
}

\author{
By RUDY HARTSKEERL, ELLY ZUIDWEG, MAARTEN VAN GEFFEN \\ AND WIEL HOEKSTRA* \\ Department of Molecular Cell Biology, State University of Utrecht, Padualaan 8, \\ 3584 CH Utrecht, The Netherlands
}

(Received 11 September 1984 ; revised 4 January 1985)

\begin{abstract}
The exclusion relationship between the IncI plasmids R144, R64 and ColIb was studied in such a way that incompatibility interference was avoided. Genetic crosses with an R144-derived Hfr donor, crosses with recipient strains carrying R144-derived exclusion genes on a recombinant plasmid compatible with R144, and measurement of transmission frequencies of a recombinant plasmid compatible with IncI plasmids after mobilization by R144 revealed that R144, R64 and Collb belong to one exclusion group.
\end{abstract}

\section{INTRODUCTION}

Conjugation between donor and recipient bacteria with identical or closely related conjugative plasmids is generally less efficient than conjugation between donor bacteria and plasmid-free recipients (Lederberg et al., 1952; Willetts \& Maule, 1974). This reduced efficiency is supposed to be the result of two distinct effects: 'exclusion' and 'incompatibility' (Novick, 1969). Exclusion interferes with the initial steps in conjugation (Sheehy et al., 1972; Achtman \& Skurray, 1977; Hartskeerl \& Hoekstra, 1984). Incompatibility operates after DNA transfer and results in plasmid segregation.

Determination of specific exclusion values in crosses is hampered by incompatibility, unless special precautions are taken. In a previous paper (Hartskeerl et al., 1983) we have described how to study exclusion by the IncI plasmid R144, without interference by the incompatibility phenomenon. Firstly, we used an R144-derived Hfr-type donor and measured the frequency of transmission of chromosomal DNA by this donor to recipient strains harbouring R144. Secondly, we constructed a recombinant plasmid (pRAH517) with a distinct fragment of R144 coding for exclusion inserted in vector pACYC184. This plasmid appeared to be compatible with R144 and it could thus be used to construct recipients that allow determination of specific exclusion values. An alternative genetic method to determine exclusion, which avoids incompatibilty, was described by Meynell (1969). He used donor strains carrying an IncI plasmid together with the compatible (and mobilizable) ColE2 plasmid and measured transmission frequencies of ColE2 in matings between these donors and recipients carrying the same or related IncI plasmids.

Instead of measuring DNA transfer indirectly by genetic means, it can also be measured directly, after labelling DNA in the donor cells and measuring the amount of labelled DNA in the recipient cells after mating (Wilkins et al., 1971). DNA transfer values measured in this way are not affected by incompatibility and should indicate exclusion values when appropriate recipients are used.

Using the various tools mentioned above, we investigated the exclusion relationship between three well known IncI plasmids: R144, R64 and ColIb. The results presented in this paper indicate that these three plasmids belong to the same exclusion group.

\footnotetext{
Abbreviations: $\mathrm{Ap}^{\mathrm{R}}$, ampicillin resistance $; \mathrm{Cm}^{\mathrm{R}}$, chloramphenicol resistance; $\mathrm{Km}^{\mathrm{R}}$, kanamycin resistance; $\mathrm{Tc}^{\mathrm{R}}$, tetracycline resistance; Exc, exclusion during R144 conjugal transfer; $\mathrm{Mob}^{+}$, mobilizable by R144 and Collb.
} 
Table 1. Escherichia coli K12 strains and plasmid types

\begin{tabular}{|c|c|}
\hline $\begin{array}{l}\text { Strain or } \\
\text { plasmid }\end{array}$ & Relevant characteristics \\
\hline \multicolumn{2}{|l|}{ E. coli strains } \\
\hline AM4000 & $\begin{array}{l}\mathrm{AB} 1157\left(\mathrm{Thr}^{-} \mathrm{Leu}^{-} \text {proA } \mathrm{His}^{-}\right. \\
\text {Thi }^{-} \mathrm{Arg}^{-} \mathrm{Lac}^{-} \mathrm{Ara}^{-} \text {rpsL } L \mathrm{ColIb}^{\mathrm{R}}\end{array}$ \\
\hline AM1281 & $\left(\mathrm{Met}^{-}\right.$rpsL) $\mathrm{Collb}^{\mathrm{R}}$ \\
\hline AM4110 & AM1281 Rpo- \\
\hline AM4179 & AM1281(pBR322) \\
\hline PC221 & Prototroph \\
\hline AM4116 & $\mathrm{PC}^{2} 21 \mathrm{Rpo}^{-}$ \\
\hline JA221 & $\mathrm{Thr}^{-} \mathrm{Leu}^{-} \mathrm{Thi}^{-} \Delta t r p E 5 \mathrm{Lac}^{-} \operatorname{rec} A$ \\
\hline AM4181 & JA221 (R144-drd3, pRAH312) \\
\hline $\mathrm{J} 53$ & Pro ${ }^{-} \mathrm{Met}^{-}$ \\
\hline AM4107 & Hfr-type, R $144^{+}$donor strain \\
\hline \multicolumn{2}{|l|}{ Plasmids } \\
\hline $\mathrm{R} 144-d r d 3$ & Colicin $\mathrm{Ib}, \mathrm{Km}^{\mathrm{R}}$ derepressed \\
\hline $\mathrm{R} 144-d r d^{+}$ & Colicin $\mathrm{Ib}, \mathrm{Km}^{\mathrm{R}}$, repressed \\
\hline Collb-drdI & Colicin Ib, derepressed \\
\hline $\mathrm{R} 64-d r d 11$ & $\mathrm{Str}^{\mathrm{R}}, \mathrm{Tc}^{\mathrm{R}}$, derepressed \\
\hline F'lac pro & \\
\hline pACYC184 & $\mathrm{Cm}^{\mathrm{R}} \mathrm{Tc}^{\mathrm{R}}$ \\
\hline pRAH517 & $\mathrm{Cm}^{\mathrm{R}} \mathrm{Exc}^{+}$ \\
\hline pRAH521 & $\mathrm{Cm}^{\mathrm{R}} \mathrm{Exc}^{-}$ \\
\hline pBR322 & $\mathrm{Ap}^{\mathrm{R}} \mathrm{Tc}^{\mathrm{R}}$ \\
\hline pRAH312 & $\mathrm{Ap}^{\mathrm{R}} \mathrm{Mob}^{+}$ \\
\hline
\end{tabular}

\begin{abstract}
Reference or source
\end{abstract}
Havekes et al. (1977)

Hartskeerl et al. (1983)

Phabagen collection

Clarke \& Carbon (1978)

This paper

Clowes \& Hayes (1968)

Hartskeerl et al. (1983)

Meynell \& Cooke (1969)

Hartskeerl \& Hoekstra (1984)

Edwards \& Meynell (1968)

Lawn et al. (1967)

CSH collection

Chang \& Cohen (1978)

Hartskeerl et al. (1983)

Hartskeerl et al. (1983)

Bolivar et al. (1977)

This work

\section{METHODS}

Bacterial strains and plasmids. Bacterial strains and plasmid types used in this investigation are listed in Table 1 . Strains for which no reference is indicated were constructed during this investigation either by conjugation or transformation.

Media. Peptone/yeast broth contained : peptone, $1 \%$; yeast extract $0.5 \% ; \mathrm{NaCl}, 0.5 \% ; \mathrm{Na}_{2} \mathrm{HPO}_{4} .2 \mathrm{H}_{2} \mathrm{O}, 1 \%$. Antibiotics were added at the following concentrations $\left(\mu \mathrm{g} \mathrm{ml}^{-1}\right)$ : streptomycin sulphate, 100 ; kanamycin sulphate, 50; tetracycline, 10; chloramphenicol, 100; ampicillin, 50; rifampicin, 40. Minimal medium was as described by Winkler \& de Haan (1948). Difco agar (1.5\%) was added to solidify the media. The medium used to label donor cells was a minimal medium containing $20 \mu \mathrm{Ci}(740 \mathrm{kBq})\left[{ }^{3} \mathrm{H}\right]$ deoxythymidine $\mathrm{ml}^{-1}$ (Amersham) supplemented with Casamino acids, thiamin and adenosine as described by Sheehy et al. (1972).

Mating. Membrane filter mating was done as described previously (Hartskeerl \& Hoekstra, 1984). Liquid matings were done by mixing exponential phase cultures of donor and recipient cells in a $1: 1$ ratio and incubating the mixtures at $37^{\circ} \mathrm{C}$ for an appropriate period. Selection of transconjugants after mating was done by plating appropriate dilutions of the mating mixtures on selective media.

DNA transfer. The amount of $\left[{ }^{3} \mathrm{H}\right] \mathrm{DNA}$ transferred from prelabelled donor cells during mating was determined as follows. Mating aggregates were, after an appropriate mating period, diluted $1: 15$ in warm brain-heart broth (Difco) supplemented with penicillin ( 500 units $\mathrm{ml}^{-1}$ ) and sodium dodecyl sulphate (SDS; $0.01 \%$ ). This suspension was incubated for $90 \mathrm{~min}$ at $37^{\circ} \mathrm{C}$ to allow lysis of the penicillin-sensitive donor cells. SDS prevents new aggregate formation (Hartskeerl \& Hoekstra, 1984) and additionally appears to enhance lysis of the donor cells. Deoxyribonuclease (Wilkins et al., 1971) and $\mathrm{MgCl}_{2}$ ( $5 \mathrm{mM}$ final concentration) were added to the mixture to degrade immediately the DNA released from the donor cells. Unlabelled deoxythymidine was added at a final concentration of $0.5 \mathrm{mg} \mathrm{ml}^{-1}$ to diminish the uptake and incorporation of the ${ }^{3} \mathrm{H}$-labelled digestion products by the recipient cells. After lysis and DNA degradation the mixtures were centrifuged in an SS34 rotor (Sorvall RC2B) at $30000 \mathrm{~g}$ for $15 \mathrm{~min}$. The pellets were resuspended in minimal medium and treated with pronase and Brij-58 (Wilkins et al., 1971), washed three times and resuspended in $0.9 \%(\mathrm{w} / \mathrm{v}) \mathrm{NaCl}$ (volume equal to the initial volume of the mating mixtures). Radioactivity in a TCA-insoluble form, transferred to the recipient cells, was determined by spotting $0 \cdot 1 \mathrm{ml}$ of the cell suspension on a glass microfibre disc (Whatman GF/A) pretreated with $10 \%(\mathrm{w} / \mathrm{v})$ TCA. The discs were rinsed consecutively in $10 \%(\mathrm{w} / \mathrm{v}) \mathrm{TCA}, 5 \%(\mathrm{w} / \mathrm{v})$ TCA and $96 \%(\mathrm{v} / \mathrm{v})$ ethanol (Sheehy et al., 1972) at $0^{\circ} \mathrm{C}$, dried and subsequently placed in vials containing $5 \mathrm{ml}$ Picofluor (Packard). The amount of radioactivity, determined as described above, was corrected for the small amount of donor DNA incorporated after lysis of the donor cells as determined in a specific control experiment. In such an experiment, labelled donor cells were lysed, the lysate was treated with nuclease and the mixture added to recipient cells together with 
deoxythymidine. After incubation for $90 \mathrm{~min}$, the amount of radioactivity incorporated by the recipient cells was determined. Correction was made for the amount of non-specifically bound radioactivity found in another control experiment where heat-killed recipient cells were used instead of viable mating-proficient recipient cells.

\section{RESULTS}

\section{Exclusion determined by measuring transconjugant formation in crosses with an Hfr-type donor}

To study the exclusion relationship between the IncI plasmids R144, R64 and ColIb we used the R144-derived Hfr-type donor AM4107 and measured the frequency of transconjugant formation in crosses with appropriate recipients. Plasmid R64 or ColIb, when present in the recipient, reduced transconjugant formation by the same order of magnitude as R144 (Table 2). Transfer of chromosomal DNA by strain AM4107, however, occurred with a rather low efficiency (see legend, Table 2 ) and the conclusions are consequently based on low figures. We therefore used alternative methods to measure exclusion values.

\section{Exclusion determined by measuring transmission of the recombinant plasmid pRAH312}

pRAH312 is a recombinant plasmid derived from pBR322 after insertion of a distinct 1.65 MDal BglII fragment of R144 (Hartskeerl et al., 1984). pRAH312 is not self-transmissible, but it was mobilized efficiently from a $\operatorname{rec} A$ background (host strain JA221) by R144 or the closely related ColIb but less efficiently by $\mathrm{F}$ (Table 3 ). The vector pBR322 is itself, in contrast to pRAH312, very inefficiently mobilized by R144-drd3 (5.7 $\times 10^{1}$ streptomycin- and ampicillinresistant transconjugants per $\mathrm{ml}$ of mating mixture). The recombinant plasmid pRAH312 apparently harbours a region of R144 essential for its transmission (oriT). We measured transmission of pRAH312 from donor AM4181, a recA strain carrying pRAH312 together with R144-drd3, to various recipients. The results (Table 4) show that the presence in recipient cells of either R144-drd ${ }^{+}$, R144-drd3 or pRAH517, the recombinant plasmid with the exclusion gene(s) (exc) from R144, caused a significant reduction in the transmission of pRAH312. However, if pRAH521, a plasmid with an Exc- phenotype towards R144, was present in the recipient, transmission of pRAH312 was very efficient. These results demonstrate that transmission of pRAH312 is affected by exclusion encoded by R144. However, the extensive reduction in transmission observed with the recipient harbouring R144-drd3 is remarkable and probably caused by effects additional to exclusion. Transmission of pRAH312 to recipient strains harbouring the derepressed R64 or ColIb plasmids was also reduced compared with control crosses (Table 4). When the selected transconjugants obtained from crossing donor AM4181 with recipient strains harbouring R144, R64 or Collb were analysed, it appeared that pRAH312 was present as a distinct molecular species together with the various resident plasmids (details not shown). This suggests that pRAH312 stably coexisted not only with R144 but also with R64 and ColIb. The reduction factor found in transconjugant formation after transmission of pRAH312 to recipients harbouring R64 or ColIb was comparable with the reduction factor in transconjugant formation found in crosses between donor AM4107 and these recipients.

\section{Transmission of $R 64$ and ColIb to a recipient with an Exc- recombinant plasmid}

The results so far strongly suggest that R144, R64 and ColIb belong to the same exclusion group. One might thus expect high transmission of $\mathrm{R} 64$ and ColIb from $\mathrm{R}_{64}{ }^{+}$or $\mathrm{ColIb}^{+}$donors to a recipient with a recombinant plasmid (pRAH521) that does not exert exclusion towards R144. pRAH521 differs from the Exc ${ }^{+}$plasmid pRAH517 only in that a 1.25 Mdal Sall fragment derived from R144 is orientated in the opposite direction (Hartskeerl et al., 1983). However, the frequencies of R64 and ColIb transmission to a recipient with the Exc ${ }^{-}$plasmid pRAH521 were relatively low (Table 5). It is possible that the region cloned in pRAH521 harbours an additional gene or genes encoding exclusion specifically for ColIb or R64. An alternative explanation would be that pRAH521 interferes with ColIb or R64 after transfer in such a way that donor and recipient plasmids do not stably coexist. This would be consistent 
Table 2. Exclusion by IncI plasmids measured in matings with the Hfr-type donor strain AM4107

$\mathrm{Ara}^{+}$transconjugants were selected, after membrane filter mating, on selective minimal medium with arabinose as carbon source. The $\mathrm{Ara}^{+}$donor marker is an early marker for donor strain AM4107 (Hartskeerl et al., 1983). The number of $\mathrm{Ara}^{+}$transconjugants obtained with recipient AM4000 (about $10^{-4}$ to $10^{-5}$ per donor cell) served as reference. The reduction factor was determined by dividing the number of $\mathrm{Ara}^{+}$transconjugants obtained with recipient strain AM4000 by the numbers obtained with recipient strains harbouring a plasmid.

\section{Recipient}

\section{AM4000}

AM4000 (R144-drd3)

AM4000 (Collb-drdl)

AM4000 (R64-drdII)
Reduction factor

1
$6-38$
$6-25$
$15-100$

\section{Table 3. Transmission of plasmid pRAH312 by various conjugative plasmids}

Transconjugants were selected on peptone/yeast agar plates or minimal medium plates provided with the antibiotics or carbon source as indicated.

\begin{tabular}{|c|c|c|}
\hline $\begin{array}{l}\text { Donor JA221 } \\
\text { with plasmid }\end{array}$ & $\begin{array}{l}\text { Selection after mating } \\
\text { with recipient AM4000 }\end{array}$ & $\begin{array}{l}\text { No. of transconj } \\
\text { per ml of mating }\end{array}$ \\
\hline pRAH312 & $\mathrm{Str}^{R} A \mathrm{p}^{\mathrm{R}}$ & 0 \\
\hline \multirow[t]{2}{*}{ pRAH $312, \mathrm{R} 144-d r d 3$} & $\operatorname{Str}^{R} \mathrm{Km}^{\mathrm{R}}$ & $8.2 \times 10^{7}$ \\
\hline & $\operatorname{Str}^{R} A p^{R}$ & $1.8 \times 10^{7}$ \\
\hline \multirow[t]{2}{*}{ pRAH312, Collb- $d r d I$} & $\mathrm{Str}^{\mathrm{R}} \mathrm{Col}^{+}$ & $2.5 \times 10^{8}$ \\
\hline & $\operatorname{Str}^{R} A p^{R}$ & $1 \cdot 0 \times 10^{6}$ \\
\hline \multirow[t]{2}{*}{ pRAH312, F'lac pro } & $\mathrm{Str}^{\mathrm{R}} \mathrm{Lac}^{+}$ & $2.5 \times 10^{8}$ \\
\hline & $S t r^{R} A p^{R}$ & $2.3 \times 10^{2}$ \\
\hline
\end{tabular}

Table 4. Effect of various plasmids in recipient AM1281 on transmission of pRAH312 from donor AM4181

Reduction in transmission is expressed as the ratio of the number of $\mathrm{Ap}^{\mathrm{R}}$ transconjugants obtained from the mating with recipient strain $A M 1281$ to the number of $A p^{R}$ transconjugants obtained from the matings with recipient strain $A M 1281$ harbouring any of the plasmids listed. Transconjugants were selected on plates containing streptomycin and ampicillin. In cases where the recipient harboured R64$d r d 11$, transmission of R64-drdll to the donor cells might hamper the counter selection for $\operatorname{Str}^{\mathrm{R}}$ that we $^{-1}$ applied in crosses with donor AM4181. Therefore, from recipients harbouring R64-drd11 we selected $\mathrm{Ap}^{\mathrm{R}}$ colonies on minimal medium plates selective for strain AM1281.

$\begin{array}{lc}\begin{array}{c}\text { Recipient } \\ \text { plasmid }\end{array} & \begin{array}{c}\text { Reduction in } \\ \text { transmission }\end{array} \\ \text { pACYC184 } & 1 \\ \text { R144-drd3 } & 2.5 \times 10^{4} \\ \text { R144-drd+ } & 26 \\ \text { Collb-drdl } & 82 \\ \text { R64-drdll } & 60 \\ \text { pRAH517 } & 93 \\ \text { pRAH521 } & 2\end{array}$

with the observation that in crosses with $\mathrm{ColIb}^{+}$or $\mathrm{R} 64^{+}$donors, the numbers of transconjugant colonies obtained with the $\mathrm{Exc}^{-}$recipient were much lower if selection conditions required the presence of donor plasmid together with the resident plasmid. This is illustrated in Table 5 for the cross with the ColIb ${ }^{+}$donor. With recipients harbouring pRAH521 or pRAH517, such stringent selection conditions caused a significant decrease in the number of transconjugants.

\section{Exclusion determined by measuring the amount of donor DNA transferred to the recipient}

To test directly whether, in crosses with recipients harbouring pRAH517 or pRAH521, transfer of donor DNA was affected or whether post-transfer processes caused the reduction in 
Table 5. Transmission of R144, Collb and R64 to recipients carrying an Exc ${ }^{+}$or Exc ${ }^{-}$plasmid

Results are expressed as the ratio of the number of $\mathrm{Km}^{\mathrm{R}}$ transconjugant colonies obtained from the matings with recipient strains harbouring pACYC184 to the number of $\mathrm{Km}^{\mathrm{R}}$ transconjugants obtained in a similar recipient strain harbouring either pRAH517 or pRAH521. In the crosses with the R144+ donor and those with the ColIb ${ }^{+}$donor, AM1281 derivatives served as recipients. In crosses with the $\mathrm{R}^{+} 4^{+}$donor, done on a membrane filter, AM4110 derivatives served as recipients. The numbers in parentheses indicate reduction values obtained if mating selection required the presence of both donor and resident recipient plasmid.

\begin{tabular}{|c|c|c|}
\hline & \multicolumn{2}{|c|}{$\begin{array}{l}\text { Reduction of the frequency of } \\
\text { transconjugant colony formation } \\
\text { by recipients carrying: }\end{array}$} \\
\hline Donor strain & pRAH517 $\left(\mathrm{Exc}^{+}\right)$ & pRAH521 (Exc- \\
\hline $\begin{array}{l}\text { J53 (R144-drd3) } \\
\text { AM4116(Collb:: Tn5-drdl) } \\
\text { PC221 (R64::Tn5-drdll) }\end{array}$ & $\begin{array}{l}104 \\
143\left(5 \times 10^{2}\right) \\
170\end{array}$ & $\begin{array}{r}2 \\
100\end{array}\left(3 \times 10^{4}\right)$ \\
\hline
\end{tabular}

Table 6. $\left[{ }^{3} \mathrm{H}\right] D N A$ transfer and transconjugant colony formation in crosses with donor strain AM4116 (ColIb ::Tn5-drdI) and various recipients

\begin{abstract}
All recipients were derived from strain AM4179. $\left[{ }^{3} \mathrm{H}\right]$ DNA transfer was measured as described in Methods. The amount of TCA-insoluble radioactivity was 786c.p.m. Based on the label present in the donor and the efficiency of the transmission, a maximum amount of about 800 c.p.m. was expected. The values of the control experiments were $20 \mathrm{c} . \mathrm{p} . \mathrm{m}$. for uptake of label after lysis and $120 \mathrm{c} . \mathrm{p} . \mathrm{m}$. for non-specifically bound label. The results obtained with the recipient carrying the vector plasmid pACYC184 were arbitrarily taken as the $100 \%$ basis.
\end{abstract}

\begin{tabular}{|c|c|c|c|}
\hline \multirow{2}{*}{$\begin{array}{l}\text { Plasmid type in the } \\
\text { recipient and its } \\
\text { exclusion phenotype }\end{array}$} & \multirow{2}{*}{$\begin{array}{c}{\left[{ }^{3} \mathrm{H}\right] \mathrm{DNA}} \\
\text { transfer } \\
(\%)\end{array}$} & \multicolumn{2}{|c|}{$\begin{array}{c}\text { Efficiency of } \\
\text { transconjugant } \\
\text { colony formation }(\%)\end{array}$} \\
\hline & & $\mathrm{Km}^{\mathrm{R}}$ & $\mathrm{K} \mathrm{m}^{\mathrm{R}} \mathrm{Cm}^{\mathrm{R}}$ \\
\hline pACYC184 (Exc-) & 100 & 100 & 100 \\
\hline pRAH517 $\left(\mathrm{Exc}^{+}\right)^{\prime}$ & $3 \cdot 2$ & $0 \cdot 3$ & 0.07 \\
\hline pRAH521 (Exc- & $71 \cdot 4$ & $3 \cdot 1$ & 0.004 \\
\hline
\end{tabular}

transmission, the amount of donor DNA transferred to various recipients was measured. It appeared that transfer of ${ }^{3} \mathrm{H}$-labelled DNA from a ColIb ${ }^{+}$donor to a recipient harbouring pRAH517 was reduced while transfer to a recipient harbouring pRAH521 was highly efficient (Table 6). Transfer of DNA from an R64+ donor could not be measured in this way since transfer by this donor, although $d r d$, was not efficient enough. Collb transfer is thus reduced if the recipient strain harbours the Exc ${ }^{+}$plasmid pRAH517. The genetic crosses indicated that after transfer Collb was expelled to some extent in such recipients. Transfer of Collb to a recipient harbouring the $\mathrm{Exc}^{-}$plasmid pRAH521 was not affected by exclusion. After transfer, as indicated by the genetic crosses, Collb was expelled by pRAH521.

\title{
DISCUSSION
}

Our experiments were intended to elucidate the exclusion relationship between R144, R64 and ColIb. R144 and R64 have been reported to exclude each other (Hedges \& Datta, 1973). That conclusion was reached after genetic crosses where incompatibility could interfere. In our experiments we tried to determine exclusion by various experimental approaches that avoided incompatibility phenomena. These approaches consisted of (i) measurement of transfer of chromosomal DNA from an $\mathrm{Hfr}$-type strain derived from an $\mathrm{R} 144^{+}$donor; (ii) measurement of transmission of a pBR322-derived recombinant plasmid after mobilization from a $\operatorname{rec} A$ background by R144; and (iii) measurement of the amount of donor DNA transferred from an Incl-type donor in which the DNA was labelled. 
Transfer of chromosomal DNA from an $\mathrm{Hfr}$-type $\mathrm{R} 144^{+}$donor revealed that transconjugant formation was reduced to the same extent when the recipient carried R144, R64 or Collb. Likewise, transmission of the recombinant plasmid pRAH312 with R144-drd3 as mobilizing plasmid was reduced when the recipients harboured one of these IncI plasmids. In these recipients plasmid pRAH312 appeared to be stable and was found as a distinct molecular species besides the various IncI plasmids, proving that pRAH312 is compatible with these IncI plasmids. Remarkably, the transmission frequency of pRAH312 was much lower with a recipient harbouring the derepressed plasmid $\mathrm{R} 144$ than with a recipient harbouring the repressed plasmid $\mathrm{R} 144$. This enhanced reduction is probably not due to incompatibility nor to derepression of the exc gene(s), which does not occur (Hartskeerl \& Hoekstra, 1984). Apparently the establishment of pRAH312 is inhibited by an R144-encoded function which is controlled by the $d r d$ gene. The establishment of transferred plasmid DNA involves complementary strand synthesis and circularization of the double stranded plasmid DNA in a process termed repliconation (Clark \& Warren, 1979). In addition, we have found that transmission of R144 to a recipient carrying R144 was also strongly affected by the $d r d 3$ mutation (R. Hartskeerl, unpublished results). It is possible that repliconation of the transferred DNA is hampered in these cases.

The results of crosses with a recipient carrying pRAH517 suggested that low transmission of R64 and Collb is due to exclusion encoded by the R144-DNA fragment in pRAH517. The recombinant plasmid pRAH521, carrying the same R144-DNA fragment in the opposite orientation to that in pRAH517, was Exc ${ }^{-}$towards an R144+ donor (Hartskeerl et al., 1983). When the amount of donor DNA transferred from a ColIb ${ }^{+}$donor to a recipient harbouring an $\mathrm{Exc}^{+}$(pRAH517) or an $\mathrm{Exc}^{-}$(pRAH521) recombinant plasmid was measured, ColIb-DNA transfer was reduced only when the $\mathrm{Exc}^{+}$plasmid was present in the recipient. Surprisingly, however, a recipient with pRAH521 yielded reduced numbers of transconjugants when an R64 ${ }^{+}$ or a Coll ${ }^{+}$donor was used. The reduction of R64 and ColIb transmission by this recipient and also by a recipient carrying pRAH517 was more extensive when selection required the concomitant presence of donor and recipient plasmid. This suggested that the IncI plasmids R64 and Collb are incompatible with pRAH517 and pRAH521. This is unexpected since the IncI plasmid R144 is compatible with these recombinant plasmids. As yet we do not have a straightforward explanation for this incompatibility-like phenomenon and more investigations are required to elucidate this problem.

One straightforward conclusion can be drawn from our results: IncI plasmids R144, R64 and ColIb can be arranged in one exclusion group. Apparently, R64 and ColIb carry a gene or genes with similar exclusion functions as encoded by the R144 fragment cloned in pRAH517.

\section{REFERENCES}

Achtman, M. \& Skurray, R. (1977). A redefinition of the mating phenomenon in bacteria. In Microbial Interactions: Receptors and Recognition, Series $B$, vol. 3, p. 233-279. Edited by J. L. Reissig. London: Chapman \& Hall.

Bolivar, F., Rodriguez, R. L., Betlach, M. C., Heyneker, H. L., Boyer, H. W., Crosa, J. H. \& FALKOW, S. (1977). Construction and characterization of new cloning vehicles II. A multipurpose cloning system. Gene 2, 95-113.

Chang, A. C. Y. \& Cohen, S. N. (1978). Construction and characterization of amplifiable multicopy DNA cloning vehicles derived from the PI5A cryptic miniplasmid. Journal of Bacteriology 134, 1141-1156.

Clark, A. J. \& Warren, G. J. (1979). Conjugal transmission of plasmids. Annual Review of Genetics 13, 99-125.

Clarke, L. \& Carbon, J. (1978). Functional expression of cloned yeast DNA in Escherichia coli: specific complementation of argininosuccinate lyase $(\operatorname{argH})$ mutations. Journal of Molecular Biology 120, 517532.

Clowes, R. C. \& Hayes, W. (1968). Experiments in Microbial Genetics. Oxford, Edinburgh: Blackwell.

Edwards, S. \& Meynell, G. G. (1968). General method for isolating de-repressed bacterial sex factors. Nature, London 219. 869-870.

Hartskeerl, R. A. \& Hoekstra, W. P. M. (1984). Exclusion in IncI-type Escherichia coli conjugations: the stage of conjugation at which exclusion operates. Antonie ran Leeuwenhoek 50, 113-124.

Hartskeerl, R. A., Bergmans, J. E. N., Kamp, M. C. \& Hoekstra, W. P. M. (1983). Cloning of an exclusion-determining fragment of the IncI plasmid R144. Plasmid 10, 11-20.

Hartskeerl, R. A., VAN der Guchte, M., Zuidweg, E. M. \& Hoekstra, W. P. M. (1984). Physical and genetic characterization of the IncI plasmid R144drd3. Plasmid 12, 215-217.

Havekes, L., Tommassen, J., Hoekstra, W. \& 
LUGTENBERG, B. (1977). Isolation and characterization of Escherichia coli $\mathrm{K} 12 \mathrm{~F}^{-}$mutants defective in conjugation with an I-type donor. Journal of Bacteriology 129, 1-8.

Hedges, R. W. \& Datta, N. (1973). Plasmids determining I pili constitute a compatibility complex. Journal of General Microbiology 77, 19-25.

Lawn, A. M., Meynell, G. G., Meynell, E. \& DATTA, N. (1967). Sex pili and classification of sex factors in the Enterobacteriaceae. Nature, London 216, 343-346.

LederberG, J., Cavalli, L. L. \& Lederberg, E. M. (1952). Sex compatibility in Escherichia coli. Genetics 37, 720-730.

Meynell, E. \& CoOKe, M. (1969). Repressor-minus and operator constitutive de-repressed mutants of $F$ like $\mathbf{R}$ factors. Their effect on chromosomal transfer by HfrC. Genetical Research 14, 309-313.

Meynell, G. G. (1969). Exclusion, superinfection immunity and abortive recombinants in $\mathrm{I}^{+} \times \mathrm{I}^{+}$ bacterial crosses. Genetical Research 13, 113-115.

Novick, R. P. (1969). Extrachromosomal inheritance in bacteria. Bacteriological Reviews 33, 210-235.

Sheehy, R. J., OrR, C. \& Curtiss, R., III. (1972). Molecular studies on entry exclusion in Escherichia coli minicells. Journal of Bacteriology 112, 861869.

Wilkins, B. M., Hollom, S. E. \& Rupp, W. D. (1971). Deoxyribonucleic acid transferred from ultravioletirradiated excision-defective Hfr cells of Escherichia coli K-12. Journal of Bacteriology 107, 505-512.

WILlETTS, N. \& MAULE, J. (1974). Interactions between the surface exclusion systems of some F-like plasmids. Genetical Research 24, 81-89.

Winkler, K. C. \& DE HAAN, P. G. (1948). On the action of sulfanilamide. XII. A set of non-competitive sulfanilamide antagonists for Escherichia coli. Archives of Biochemistry 18, 97-107. 